\title{
Seasonal Variation and Diversity of Hoverflies Fauna (Dipter: Syrphidae) in Central Sindh, Pakistan
}

\section{Attaullah Ansari* and Nasreen Memon}

Department of Zoology University of Sindh, Jamshoro, Pakistan.

\begin{abstract}
Diversity and seasonal variation in abundance of Hoverflies (Diptera: Syrphidae) fauna were studied in five different habitats of various localities of central Sindh during March to December 2015. Adult specimens were captured/trapped through Malaise trap, Yellow pan water trap and insect hand net. As a result, a total of 783 specimens belonging to 8 species, 6 genera of two subfamilies were collected, among which Episurphusbaltatus, De Geer, Eritalinus aeneus, Scopoli, and Ischiodon scutellaris, Fabricius were found to be most prevalent whereas; Eristalis arbustorum was found least in number during study period. The abundance of hoverflies fauna varied seasonally, the highest abundance was recorded in spring while lowest in autumn. Pearson's correlation coefficient results revealed that there was a strong positive and significant correlation of number of host plant species with the profusion of hoverflies whereas; temperature had a strong negative and significant correlation with the abundance of hoverflies. Moreover relative humidity, rainfall and cloudiness were also negatively correlated with hoverfly population but their correlation was not significant. Habitat wise variation in average population size, species richness, evenness and diversity index were also calculated. The highest and lowest degrees of population size, richness and evenness and diversity were recorded in agriculture crops and fodder crops, respectively.

Received | September 20, 2016; Accepted | August 10, 2017; Published | November 10, 2017

*Correspondence | Attaullah Ansari, Department of Zoology University of Sindh, Jamshoro, Pakistan; Email: ansariatta@gmail.com

Citation | A. Ansari. and N. Memon. 2017. Seasonal variation and diversity of hoverflies fauna (dipter: syrphidae) in central sindh, Pakistan. Sarhad Journal of Agriculture, 33(4): 653-660.

DOI | http://dx.doi.org/10.17582/journal.sja/2017/33.4.653.660

Keywords | Diversity, Abundance, Hoverflies, Habitats, Central Sindh
\end{abstract}

\section{Introduction}

$\mathrm{H}^{\circ}$ overflies are large and diverse group of flying insects with stripped abdomen. They are also called drone flies, flower flies or syrphid flies and move through the air more like flies, zipping from plant to plant and hover temporarily before landing. Hoverflies belong to family Syrphidae which is one of the largest families of Diptera (Kuznetsov, 2002) and consists of approximately 6000 species worldwide, grouped in three subfamilies i.e. Syrphinae, Eristalinae and Microdontinae (Thompson and Rotherary, 1998). They are very important and beneficial insect because of their two main ecological services i.e. pollination and biological control, which they provide to many ecosystems of the world, their adults serve as pollinators of different agricultural and horticultural crops, vegetables, wild plants and flowers (Lapchin et al., 1987) whereas the larvae of numerous species of subfamily Syrphinae are natural enemies or pests of many arthropods (specially aphids, thrips, scales and caterpillars), inhabitants of the nests of social animals, scavengers, herbivorous, fungivorous, inhabitants of polluted water and dung feeders, (Tooker et al., 1986) and (Ghahari et al., 2008). The knowledge regarding seasonal variation and abundance of syrphid pollinators in relation to a-biotic factors (temperature, humidity, rainfall etc) and biotic factors (floral abundance) is usually reported to be very effective in establishing different conservation strateDecember 2017 | Volume 33 | Issue 4 | Page 653 
gies of these pollinators (Souza-Silva, Fontenelle and Martins, 2001); (Hegland and Boeke, 2006); (Shebl et al., 2008). Generally the diversity is proportional to the stability of an ecosystem; higher the diversity, greater will be the stability of that ecosystem. The profusion/abundance and distribution of syrphid flies are generally correlated with the variation in abundance of number of flowering plant species and presence of flowers (Barret and Helenrm, 1987). So current study was designed as follows:

To explore hoverflies fauna, to collect the information about the current status of these flies in five vegetation types different habitats (Agriculture crops, Flowering vegetables, Fruit gardens/farms, Ornamental flowers and fodder crops). To monitor their abundance and distribution changes monthly. To find out that which habitat/plant species loaded the individual number of hoverfly is highest. To observe the effect of climatic or abiotic factors (humidity, temperature, rainfall and cloudiness) as well as biotic factors (number of species of flowering host plant) on species composition, abundance and diversity of hoverflies.

\section{Materials and Methods}

\section{Study site}

This study was carried out in different localities of central Sindh like Matiari, Hyderabad, Sanghar, Jamshoro, T.M Khan, Tando Allah yar and Mirpurkhas during March to December 2015. Central Sindh region has a hot climate with warm conditions year round. Central Sindh is the most productive region of Sindh from agricultural point of view and almost all crops, (wheat, brassica, rice, sugarcane, cotton, sunflower, okra, berseem, mango etc) are grown here. GPS Coordinates (Latitude, Longitude \& Altitude) of surveyed localities of CentralSindh were determined (Table 1).

\section{Collection of Adult Hoverflies}

In order to study diversity and seasonal variation of hoverflies, different localities of central Sindh like Matiari, Hyderabad, Sanghar, Jamshoro, T.M Khan, Tando Allah yar and Mirpurkhas during March to December 2015 were surveyed and the distance of one locality from the other was between 20 to 60 Kilometers. Adult hoverflies were collected/trapped by three standardized methods i.e. Aerial netting through insect hand net, Malaise trap and Yellow pan water trap.
In winter season hoverflies were collected between 12:00 - 16:00 whereas; in summer season they were collected in between 7:00 - 11:00 and 17:00-19:00. Collection was done fortnightly per two crops. Three Malaise traps and six yellow pan water traps were installed per locality and the frequency of collection was variable from crop to crop. After collection the specimens were brought into laboratory and put in desiccators for 24 hours for softening. Moreover setting of legs and wing venation were done on setting board and then pinned into specific wooden insect boxes for preservation. Naphthalene balls were placed in the corners of the boxes to repel fungus and other insects away. The morphological characters of these flies such as eye-pattern, wing venation, color and shape of thorax, abdomen, legs and antennae, were carefully observed under dissecting microscope, through relevant literature and authentic keys (especially Stubbs and Falk 1996) for species identification. Male and female hoverflies were identified mainly by the shape and size of their eyes.

Table 1: GPS Coordinates (Latitude, Longitude E' Altitude) of surveyed localities of Central Sindh

\begin{tabular}{|c|c|c|c|}
\hline \multirow[t]{2}{*}{ Name of locality } & \multicolumn{3}{|l|}{ Coordinates } \\
\hline & Longitude & Latitude & $\begin{array}{l}\text { Altitude } \\
\text { (in meters) }\end{array}$ \\
\hline 1.Hyderabad & $25.2245^{\circ} \mathrm{N}$ & $68.2206^{\circ} \mathrm{E}$ & 13 \\
\hline 2. Matiari & $25.3546^{\circ} \mathrm{N}$ & $68.2648 ” \mathrm{E}$ & 13 \\
\hline 3. Hala & $25.5737^{\circ} \mathrm{N}$ & $68.4122^{\circ} \mathrm{E}$ & 39 \\
\hline 4. Saeedabad & $25.5737^{\circ} \mathrm{N}$ & $68.2256^{\circ} \mathrm{E}$ & 40 \\
\hline 5. Tandojam & $25.4278^{\circ} \mathrm{N}$ & $68.5279^{\circ} \mathrm{E}$ & 14 \\
\hline 6. Tando Allah yar & $25.4587^{\circ} \mathrm{N}$ & $68.7260^{\circ} \mathrm{E}$ & 39 \\
\hline 7. T.M Khan & $25^{\circ} 7^{\prime} 23 \mathrm{~N}$ & $68^{\circ} 32^{\prime} 9 \mathrm{E}$ & 11 \\
\hline 8. Jamshoro & $25^{\circ} 7248^{\prime \prime} \mathrm{N}$ & $\begin{array}{l}68^{\circ} 2752^{\prime \prime} \\
\mathrm{E}\end{array}$ & 39 \\
\hline 9. Sanghar & $25^{\circ} 3948^{\prime \prime} \mathrm{N}$ & $\begin{array}{l}68^{\circ} 57^{\prime} 80^{\prime \prime} \\
\mathrm{E}\end{array}$ & 25 \\
\hline
\end{tabular}

\section{Data analysis}

\section{Simpson's diversity index}

Diversity of hoverfly communities in different habitats was calculated using Simpson's diversity index by following equation

$$
\mathrm{D}=\frac{\sum \mathrm{n}(\mathrm{n}-1)}{\mathrm{N}(\mathrm{N}-1)}
$$

Where: 
$\Sigma=$ sum of (total)

$\mathrm{n}=$ the number of individuals of a particular species

$\mathrm{N}=$ the total number of individuals of all the species

After calculating D, Simpson's reciprocal index was employed by dividing $\mathrm{D}$ with 1 i.e.

Simpsons reciprocal index $=1 / \mathrm{D}$

For the calculation of species evenness, Simpson's evenness index was employed using following equation

$$
\mathrm{E} 1 / \mathrm{D}=\frac{1 / \mathrm{D}}{\mathrm{S}}
$$

Where:

$\mathrm{E} 1 / \mathrm{D}=$ Simpson's measure of Evenness

$\mathrm{D}=$ Simpson's diversity index

$\mathrm{S}=\mathrm{No}$ : of species in a sample

The average population was calculated by dividing total number of individuals $(\mathrm{N})$ with species number (S).

\section{Statistical analysis}

The data were analyzed statistically using Pearson's correlation coefficient to measure the strength of linear relationship of biotic (host plants) and a-biotic (temperature, humidity, rainfall and cloudiness) factors with the abundance of hoverflies through SPSS 22 version software.

\section{Data of climatic factors}

The data of weather variables i.e. Temperature, humidity, rainfall and cloudiness of studied localities were collected from Regional Agromet Centre Tandojam, Sindh.

\section{Results and Discussion}

Results

The results of present study revealed that a total of 783 specimens belonging to 8 species, 6 genera of 2 subfamilies were recorded from five different habitats in various localities of central Sindh during March to December 2015. The individuals of sub-family Syrphinae were higher (435) in abundance than that of Eristalinae (348) throughout study period. Three most prevalent species were Episurphusbaltatus (De Geer, 1776), Eritalinus aeneus (Scopoli, 1763) and Ischiodon scutellaris (Fabricius, 180), (Figure 4).The abundance of hoverfly species varied seasonally, the population was recorded high in spring followed by summer and minimum population was recorded in autumn (Table 4 and Figure 10). Monthly population dynamics of hoverflies revealed that the abundance of hoverfly species was recorded very high during the months of March (173) and April (158) followed by December (152) whereas; they were found least abundant (12) in the month of May (Figure 3). Different host plants/habitats were categorized in five groups i.e. agriculture crops, flowering vegetables, fruit gardens/farms, ornamental flowers and fodder crops and the diversity of hoverfly communities in these five habitats was calculated (Table 3). The agriculture crops had the highest number of individual (213) followed by flowering vegetables (159) individuals, while the fodder crops had the lowest number (129) of individuals, resulting in greatest average population size $(26.62 \%)$ in agriculture crops and least population size in fodder crops (16.25\%) as shown in (Table 3). Besides this Simpsons evenness index was computed, this index was found very high (0.8454) in agriculture crops followed by flowering vegetables (0.8384) while the least Simpson's evenness index (0.7744) was in fodder crops (Table 4 and Figure 1). Finally to measure diversity, Simpson's reciprocal diversity index was employed, this index was found high in agriculture crops (6.467) followed by flowering vegetables (6.188) while the lowest diversity index (4.432) was recorded in fodder crops (Table 4 and Figure 2).

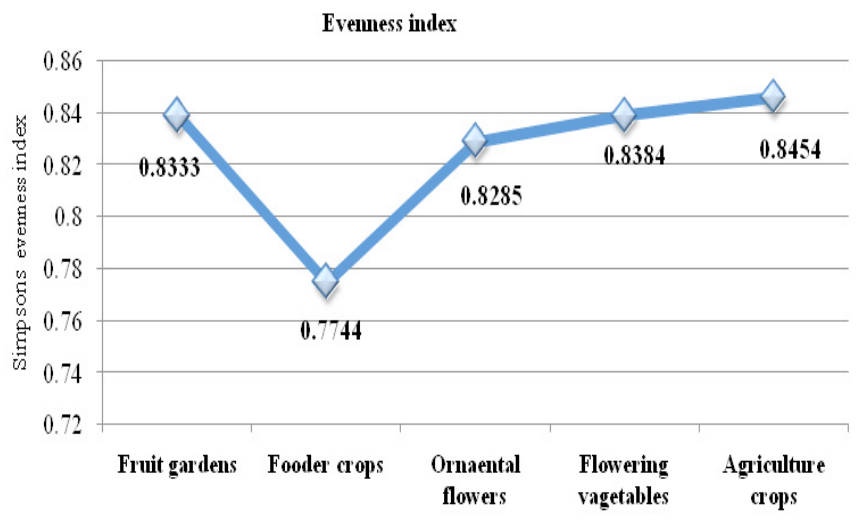

Figure 1: Simpson's evenness index of Hoverfly population in five different habitats of Central Sindh during March-Dec 2015

Pearson's correlation coefficient analysis revealed strong, positive and significant correlation i.e. $r=.912$ $(p=.001)$ between number of host plants and abundance of hoverflies, whereas; there was a strong negative and significant correlation $(r=-.609$ and $p=.047)$ of temperature with abundance of hoverflies. Moreover rainfall, relative humidity and cloudiness were also negatively correlated with the abundance of hoverflies in studied localities, the values being $\mathrm{r}=-.184 \& \mathrm{p}=.58$ 
Table 2: Metrological observations and abundance of hoverflies in Central Sindh duringMarch-December 2015

\begin{tabular}{|c|c|c|c|c|c|c|c|}
\hline \multirow[t]{2}{*}{ Month } & \multirow{2}{*}{$\begin{array}{l}\text { Total Rain (mean) } \\
\text { mm }\end{array}$} & \multicolumn{3}{|c|}{ Temperature } & \multirow{2}{*}{$\begin{array}{l}\text { Relative Humidity } \\
\%\end{array}$} & \multirow{2}{*}{$\begin{array}{l}\text { Cloudiness } \\
\text { (Octas) }\end{array}$} & \multirow[t]{2}{*}{ Abundance of hoverflies } \\
\hline & & $\begin{array}{l}\text { Min: } \\
{ }^{\circ} \mathbf{C}\end{array}$ & $\begin{array}{l}\text { Max: } \\
{ }^{\circ} \mathrm{C}\end{array}$ & $\begin{array}{l}\text { Average } \\
{ }^{\circ} \mathbf{C}\end{array}$ & & & \\
\hline March & Traces & 15.6 & 33.2 & 24.4 & 51 & 0.5 & 173 \\
\hline April & 0.2 & 22.2 & 34.1 & 28.15 & 53 & 0.9 & 158 \\
\hline May & 0.1 & 27.5 & 48.9 & 37.2 & 50 & 1.6 & 12 \\
\hline June & 0.02 & 26.3 & 47.6 & 37.1 & 58 & 0.9 & 20 \\
\hline July & 0.03 & 26.9 & 46.2 & 36.55 & 61 & 2.6 & 26 \\
\hline August & 1.3 & 26 & 38.2 & 32.1 & 59 & 3.9 & 64 \\
\hline September & 4.5 & 24.9 & 34.6 & 29.75 & 71 & 0.2 & 68 \\
\hline October & 1.2 & 19.4 & 35.1 & 27.25 & 59 & 0.4 & 60 \\
\hline November & 0.02 & 15.3 & 32.7 & 24 & 56 & 0.1 & 46 \\
\hline December & 0 & 8.7 & 25.3 & 17 & 55 & 0.3 & 152 \\
\hline
\end{tabular}

Source of metrological data: Regional Agromet Centre Tandojam

Diversitv Index

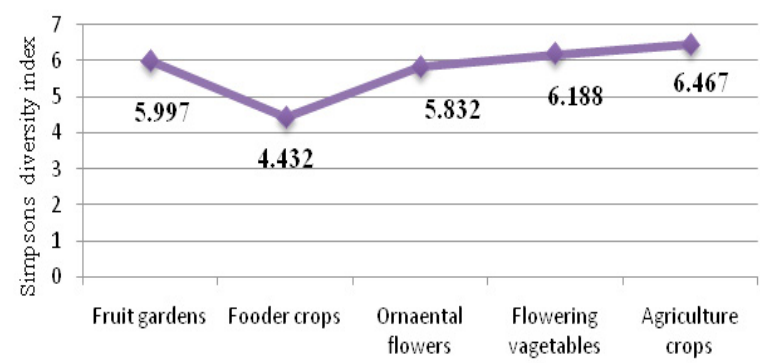

Figure 2: Simpson's diversity Index of Hoverfly communities in five different habitats of Central Sindh during March-Dec 2015

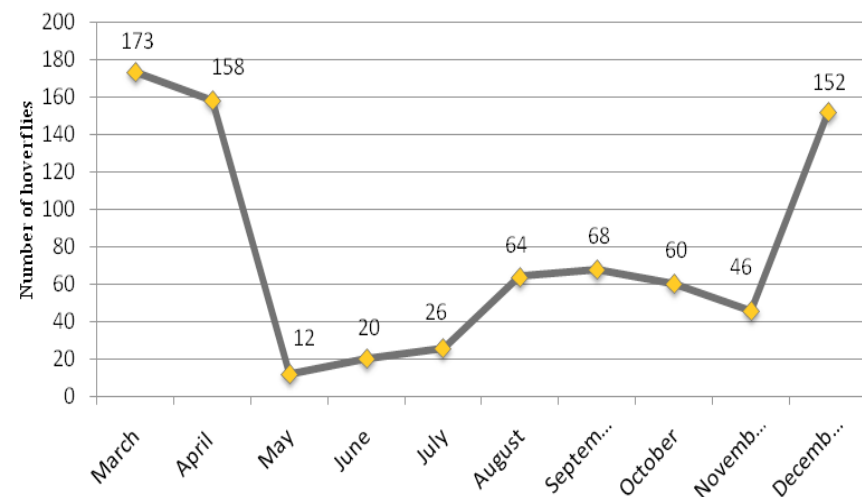

Figure 3: Month wise distribution of hoverflies during March-December 2015 from different localities of central Sindh

-7 (with rainfall); $r=-.484 \& \mathrm{p}=.131$ (with relative humidity); $r=-.451 \& \mathrm{p}=.164$ (with cloudiness) respectively. (Table 5, Figure 5,6,7,8 and 9). The p value of these three weather variables was $(>0.05)$ which indicated that their correlation with abundance of hoverfly species was not significant.

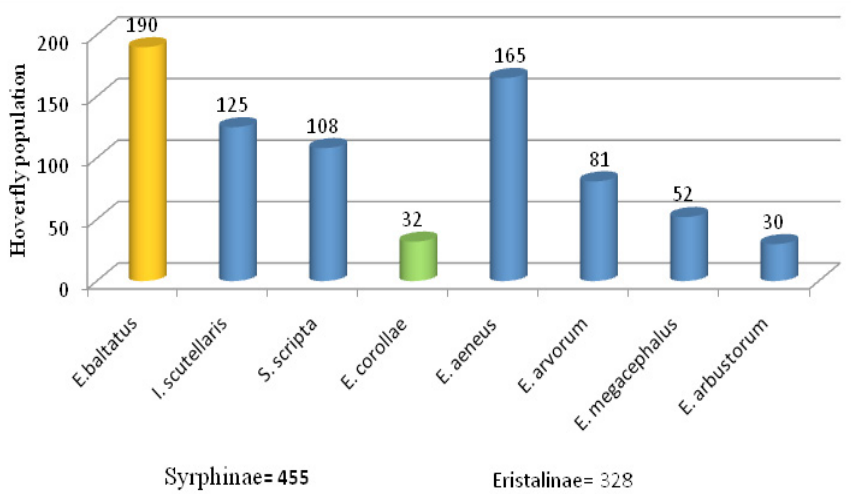

Figure 4: Species wise composition of hoverfly abundance in studied localities of central Sindh during March-Dec 2015

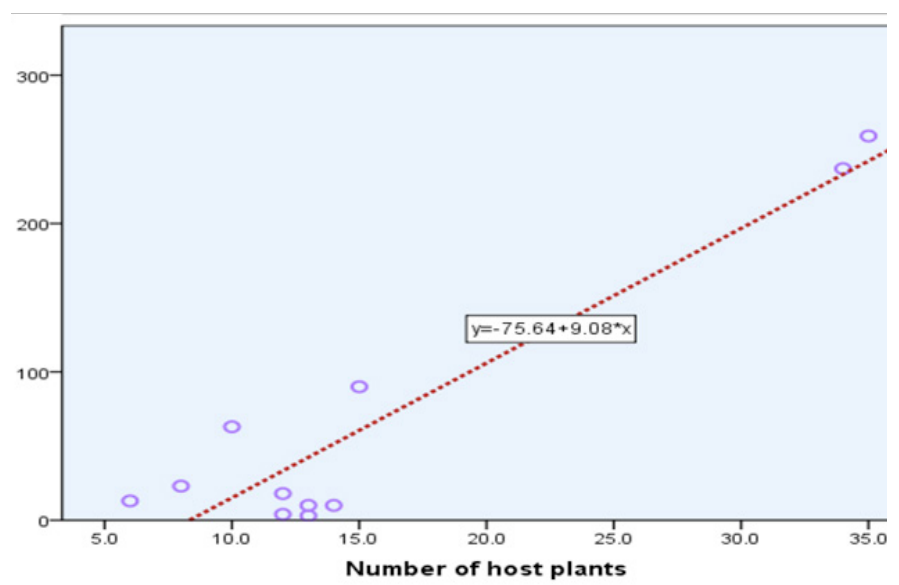

Figure 5: Relationship between number of host plants and abundance of hoverflies in Central Sindh during March-Dec 2015

Main field observations

In winter season, hoverfly communities were found 
Table 3: Seasonal variation in abundance of hoverflies and their host plants and their vegetation types in Central Sindh during March-Dec 2015

\begin{tabular}{|c|c|c|c|c|}
\hline Season & Months & $\begin{array}{l}\text { Hoverflies } \\
\text { abundance }\end{array}$ & $\begin{array}{l}\text { Number of } \\
\text { species of } \\
\text { host plants }\end{array}$ & Type of vegetation \\
\hline Spring & $\begin{array}{l}\text { March and } \\
\text { April }\end{array}$ & 331 & 15 & $\begin{array}{l}\text { Mango (magniferaindica) wheat (Triticumaestivum)Maize (Zea mays), } \\
\text { Eggplant (Solanummelongena), Berseem (Trifoliumalexandrinum), } \\
\text { Lucerne/Alfaalfa (medicago sativa), Jantar (sesbaniabispinosa), Lemon } \\
\text { (citrous lemon), Green chilli (Capsicum annum),Static plant (Limoni- } \\
\text { umperezii) Rose (Rosa indica), Cape daisy (Ursiniaspeciosa), Yellow bell } \\
\text { (Allamanda), Daisy (Bellisperennis), Amarillo (Tageteserecta) }\end{array}$ \\
\hline Summer & $\begin{array}{l}\text { May, June, } \\
\text { July, August, } \\
\text { September }\end{array}$ & 190 & 9 & $\begin{array}{l}\text { Watermelon (Citrulluslanatus), Genda (Tageteserecta), Static plant (Limo- } \\
\text { niumperezii), Okra (Abelmoschusesculentus), Eggplant (Solanummelongena), } \\
\text { Toori(Luffaacutangula),Cabbage (Brassica oleracea) Cauliflower (Brassi- } \\
\text { caoleraceavar), Spinach/Palak (Spinaciaoleracea), Brinjal (Solanummelon- } \\
\text { gena) }\end{array}$ \\
\hline Autumn & $\begin{array}{l}\text { October, } \\
\text { November }\end{array}$ & 110 & 5 & $\begin{array}{l}\text { Genda (Tageteserecta), Cotton (Gossypiumbarbadense), Jantar (sesbania- } \\
\text { bispinosa), Lucerne/Alfaalfa (medicago sativa), Onion (Allium cepa L) }\end{array}$ \\
\hline Winter & December & 152 & 7 & $\begin{array}{l}\text { Field mustard/Toorio (Brassica campestris), Weeds, Rose flower (Rosa ind- } \\
\text { ica), Genda (Tageteserecta), Soorajmukhi/ Sunflower (Helianthus annuus), } \\
\text { Janbho (Taramira/angula), Okra (Abelmoschusesculentus) }\end{array}$ \\
\hline
\end{tabular}

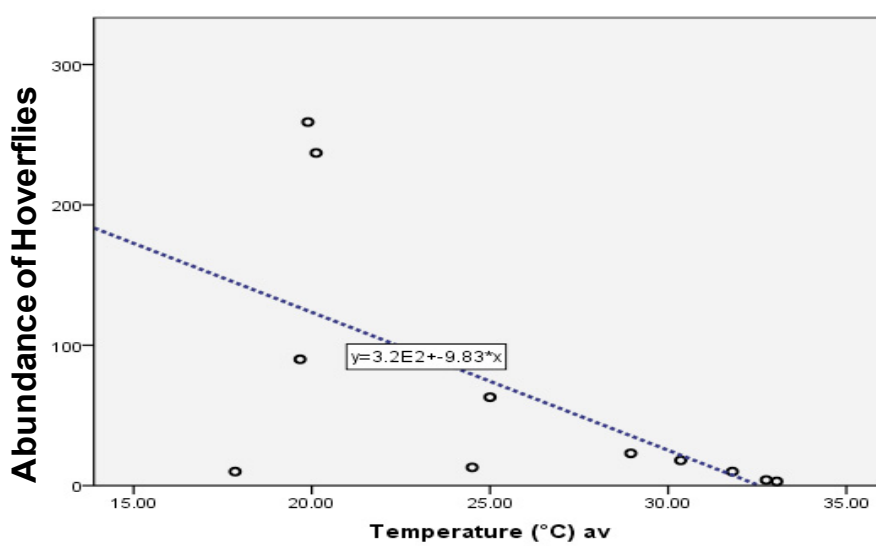

Figure 6: Relationship between average temperature and abundance of hoverflies population in Central Sindh during March-Dec 2015

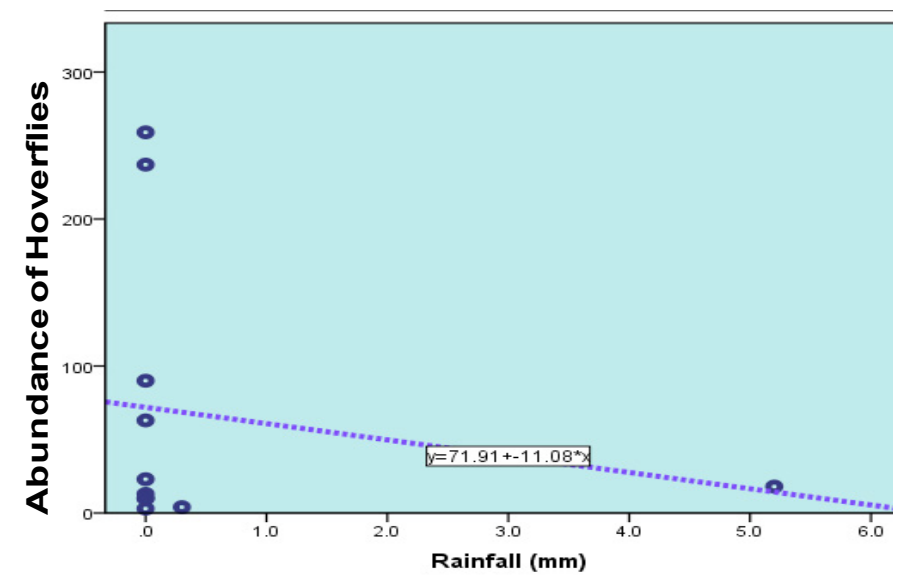

Figure 7: Relationship between rainfall and abundance of hoverflies in Central Sindh during March-Dec 2015

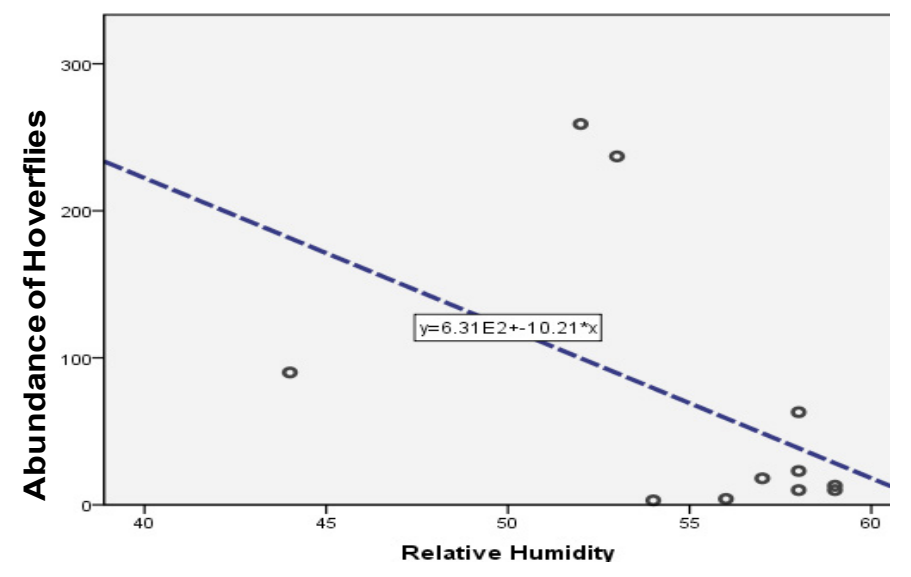

Figure 8: Relationship between relative bumidity and abundance of hoverflies in Central Sindh during MarchDec 2015

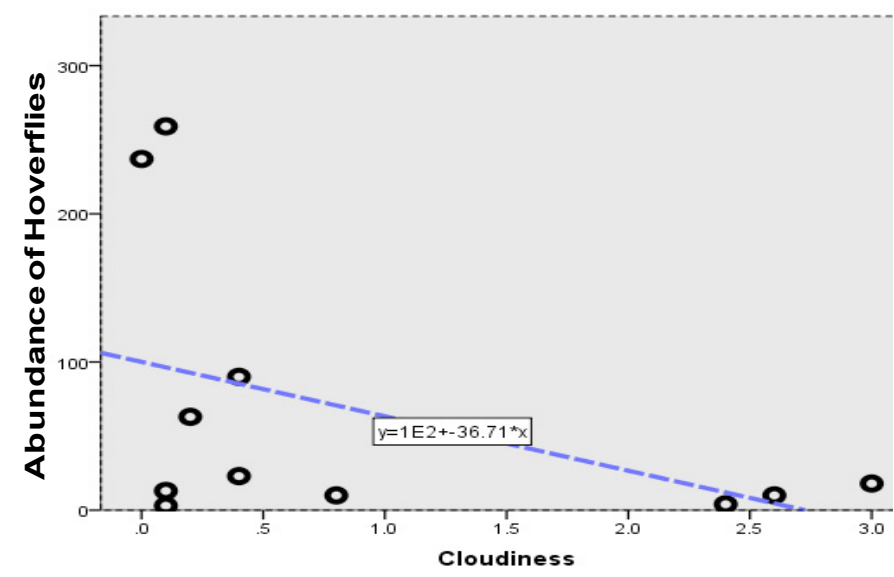

Figure 9: Relationship between cloudiness and abundance of hoverflies in Central Sindh during March-Dec 2015 
Table 4: Diversity of hoverfly communities in five habitats of Central Sindh during March-Dec 2015

$\begin{array}{lllllll}\text { Habitat type } & \begin{array}{l}\text { Species } \\ \text { number (S) }\end{array} & \begin{array}{l}\text { Individual } \\ \text { number (N) }\end{array} & \begin{array}{l}\text { Average } \\ \text { population size }\end{array} & \begin{array}{l}\text { Species } \\ \text { richness Index }\end{array} & \begin{array}{l}\text { Evenness Index } \\ \text { E(1/D) }\end{array} & \begin{array}{l}\text { Diversity } \\ \text { Index }\end{array} \\ \text { Agriculture crops } & 8 & 213 & 26.62 \% & 7.86 & 0.8454 & 6.467 \\ \text { Flowering vegetables } & 8 & 159 & 19.88 \% & 7.46 & 0.8384 & 6.188 \\ \text { Fruit gardens/farms } & 8 & 146 & 18.25 \% & 7.42 & 0.8333 & 5.997 \\ \text { Ornamental flowers } & 7 & 136 & 17 \% & 6.83 & 0.8285 & 5.832 \\ \text { Fodder crops } & 7 & 129 & 16.25 \% & 6.72 & 0.7744 & 4.432\end{array}$

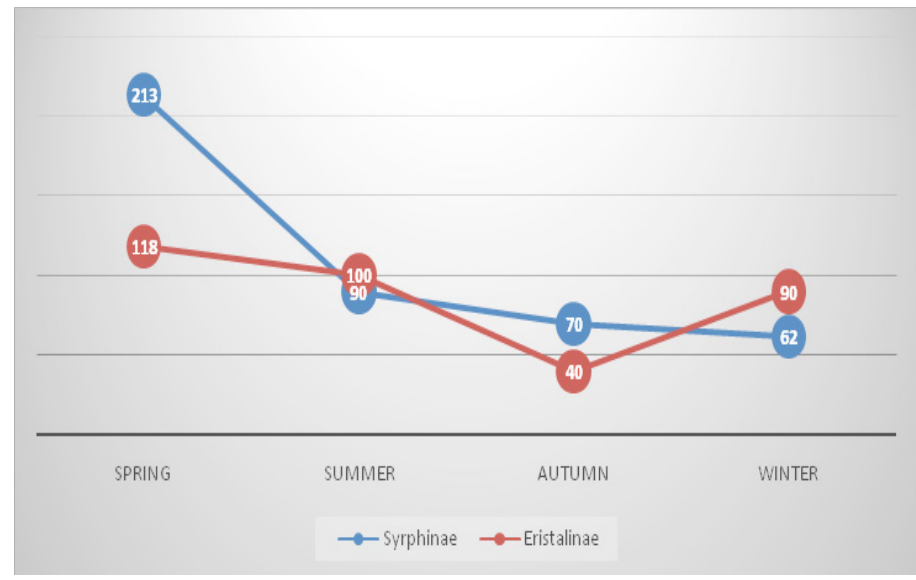

Figure 10: Seasonal variation in abundance of Syrphinae and Eristalinae hoverflies in Central Sindh during March-Dec 2015

Table 5: Relationship between number of hoverflies and biotic \& abiotic factors in Central Sindh during MarchDec 2015

$\begin{array}{lll}\text { Parameters } & \text { Pearson Correlation ' } \mathbf{r} & \text { (p value) } \\ \text { No. of host plants } & .912^{*} & .001 \\ \text { Av. Temperature }\left({ }^{\circ} \mathrm{C}\right) & -.609^{*} & .047 \\ \text { Rainfall }(\mathrm{mm}) & -.184 & .587 \\ \text { Relative Humidity }(\%) & -.484 & .131 \\ \text { Cloudiness } & -.451 & .164\end{array}$

${ }^{* * *}$ Correlation is significant at the 0.01 level (2-tailed); *Correlation is significant at the 0.05 level (2-tailed).

more active between 12:00 noon to 4:00 pm while during summer season they were found more active in the morning between 8:00 am to 12:00 noon and in the evening between 4:00 to 6:00 $\mathrm{pm}$.

Hoverflies belonging to subfamily Syrphinae were found more sensitive to environmental factors especially temperature and their population was minimum during hot months i.e. May, June and July (temperature range $38.2^{\circ} \mathrm{C}$ to $43.9{ }^{\circ} \mathrm{C}$ ) and cold months i.e. November December (temperature range $8.7^{\circ} \mathrm{C}$ to $\left.15.3{ }^{\circ} \mathrm{C}\right)$.
Wind, clouds and rainfall had negative effect on abundance of hoverflies and their population was less in those days when these factors were present (Table 2)

The highest abundance of hoverflies was found in those crops which are not frequently sprayed (especially Brassica, Lucerne, Berseem etc) with insecticides.

\section{Discussion}

The seasonal dynamics divulged that the hoverflies remain active through the year with incredible fluctuations in their abundance and distribution. Hoverflies belonging to subfamily Syrphinae were found more abundant than Eristalinae in five different habitat types in different localities of central Sindh during March to December 2015. The profusion of any hoverfly species at a particular time in particular habitat heavily depends on presence of host plant, flowers, and food for both adult and larvae, Potts et al. (2003); besides this a- biotic factors such as temperature and humidity also play a vital role in abundance and distribution of these flies. In central Sindh during spring season, the abundance of plant species was very high and most of the plants were in flowering, this had very strong positive and significant effect on the abundance of hoverflies and their population was recorded very high in this season. The climatic factors such as temperature, rainfall, relative humidity and cloudiness were found negatively correlated with the abundance of hoverflies. Among these factors only temperature had significant correlation $(\mathrm{p}<$ 0.05 ) whereas; rainfall, relative humidity and cloudiness were not significantly correlated ( $p>0.05)$ with the abundance of hoverflies. The relation between pollinators (including hoverflies) and climatic factors usually vary with geographical distribution, Carvolho et al. (1991) reported a positive correlation between temperature and number of syrphids in trop- 
ics, while in subtropical areas of the world including Pakistan this relation could be negative as reported by (Sajjad et al., 2010). Our results were also in accordance with the findings of (Sajjad et al., 2010) and climatic factors (temperature, rainfall, relative humidity and cloudiness) were negatively correlated with hoverfly abundance. Members of subfamily Eristalinae were found more tolerant to environmental factors (temperature and humidity) than Syrphinae, since these were recorded in good numbers in hottest $\left(46^{\circ} \mathrm{C}\right)$ months of May and June and coldest $\left(10^{\circ} \mathrm{C}\right)$ month of December, while the members of subfamily Syrphinae were more active during spring and winter seasons. Among five different habitats, the species composition was dissimilar i.e. the agriculture crops habitat had the highest abundance and average population size which led to high richness and diversity index, this is due to the reason that the large numbers of vegetation types such as wheat, cotton, rice, maize etc. come under agriculture crops and are grown in different seasons at large scale. On the other hand the fodder crops habitat have less number of vegetation types (berseem and lucern only) and least abundance and average population size of hoverfly species, resulting in low richness, evenness and diversity index; this is due to fact that fodder crops have less flowering period as compared to other crops.

\section{Conclusions}

It is concluded from this study that both abiotic and biotic factor play a vital role in abundance and distribution of hoverflies. More over the habitat having high average population size, richness and evenness led to high diversity index whereas; the habitat having low population size, richness and evenness resulted in lower diversity index. The abundance of syrphinae (aphidophagus) hoverflies was high than Eristalinae (saprophagous) hoverflies especially during summer season (when the aphid population was also found high), this indicates that larval diet also plays very important role in shaping population dynamics of hoverflies.

\section{Author's Contribution}

Attaullah Ansari conceived the idea and was the main investigator of this study. He collected and identified specimens up to species level, analyzed data statistically and submitted the final draft of manuscript. Nasreen Memon designed the study and supervised the overall research work.

\section{Acknowledgement}

We are highly grateful to Higher Education Commission Islamabad Pakistan for their partial financial support as this paper is partially from the HEC funded project No.203838/NRPU/P\&D/HEC/14.

\section{References}

Barrett, S.C.H. and K. Helenurm. 1987. The reproductive biology of boreal forest herbs. I. breeding systems and pollination. Can. J. Bot. 65: 2036-2046. https://doi.org/10.1139/b87278

Carvalho, A.M.C., J. Mendes, C.H. Marghiori and C. Lomônaco. 1991. Variação espacial esazonal de dipterous muscóides em duas áreas decerrado no município de Uberlândia - MG. Calliphoridae e Muscidae. R. Cent. Ci. Bioméd. Univ.Fed. Uberlândia. 7: 27-34.

Ghahari, H., R. Hayat, M. Tabari and H. Ostovan. 2008. Hoverflies (Diptera:Syrphidae) from rice fields and around grasslands of Northern Iran. Mun. Ent. Zool. 3: 275-283.

Hegland, S. J., and L. Boeke. 2006. "Relationships between the Density and Diversity of Floral Resources and Flower Visitor Activity in a Temperate Grassland Community." Ecol. Entomol. 31: 532-538. https://doi. org/10.1111/j.1365-2311.2006.00812.x

Kuzentsov, S. Yu. 2002. The Phylogeny of the Family Syrphidae (Diptera), in Proceedings of the12th Congress of Russian Entomological Society. Pp 189.

Lapchin L., A. Ferran, G. Iperti. 1987. Coccinellids (Coleoptera: Coccinellidae) and syrphids (Diptera: Syrphidae) as predators of aphids in cereal crops: a comparison of sampling methods. Can. Ent. 119: 815-822. https://doi. org/10.4039/Ent119815-9

Naderloo, M and S.P. Rad 2014. Diversity of Hoverfly (Diptera: Syrphidae) Communities in Different Habitat Types in Zanjan Province, Iran ISRN Zoology. 2014:1-5. https://doi. org/10.1155/2014/162343

Potts, S.G., B. Vulliamy, A. dafni, Ne'eman and P. Willmer. 2003. Linking bees and flowers: how do floral communities structure pollinator communities? Ecology. 84:2628. https://doi. org/10.1890/02-0136

Sajjad, A. Saeed,S. and Ashfaq, M. 2010. Seasonal

December 2017 | Volume 33 | Issue 4 | Page 659 
Variation In abundance and composition of Hoverfly (Diptera: Syrphidae) communities in Multan, Pakistan. Pakistan J. Zool. 42(2):105115.

Shebl, M. A., S. M. Kamel, T. A. Abuhashesh, and M. A. Osman. 2008. "Seasonal Abundance of Leafcutting Bees (Megachile minutissima, Megachilida, Hymenoptera).W. J. Agri. Sci. 4: 280-287.

Souza-Silva, M., J.C.R. Fontenelle and R.P. Martins.2001. Seasonoal abundance and species compositon of flower-visiting flies. Neotrop. Ent. 30: 351359. https://doi.org/10.1590/ S1519-566X2001000300002

Steffan-Dewenter I, U. Münzenberg, C. Bürger, C. Thies and T. Tscharntke. 2002. Scale-dependent effects of landscape structure on three pollinator guilds. EcoL. 83: 1421-1432. https://doi. org/10.1890/0012-9658(2002)083[1421:SDE OLC]2.0.CO;2

Stubbs, A. and S. Falk. 1996. British Hoverflies: An Illustrated Identification Guide. Reading: British Entomological and Natural History Society. Pp 469.

Thompson, F.C. and G.E Rotherary 1998. Family Syrphidae Manual of Palaearctic Diptera vol.3 (ed. by papp \& B. Darvas), 880p. Science herald, Budapest.

Tooker, J.F., M. Hauser and L.M. Hanks. 1986. Floral host plants of Syrphidae and Tachinidae (Diptera) of Central Illinois. Ann. Entomol.Soc. Am. 99: 96-112. https://doi.org/10.1603/00138746(2006)099[0096:FHPOSA]2.0.CO;2 